\title{
Article
}

\section{Phenotype characterization of human adipose-derived stem cell by flow cytometry}

\author{
Celeste Limoli ${ }^{1}$, Paolo Giuseppe Limoli ${ }^{1}$ and Marcella Nebbioso ${ }^{2, *}$
}

1 Low Vision Research Centre of Milan, Piazza Sempione 3, 20145, Milan, Italy; celeste.limoli@libero.it; paololimoli@libero.it

2 Department of Sense Organs, Ocular Electrophysiology Centre, Umberto I Policlinic, Sapienza University of Rome, Viale del Policlinico 155, 00161, Rome, Italy; marcella.nebbioso@uniroma1.it

* Correspondence: celeste.limoli@libero.it;

Abstract: Background: Developing an efficient and standardized method to isolate and characterize adipose-derived stem cells (ASCs) from the stromal vascular fraction (SVF) of the adipose tissue for clinical application represents one of the major challenges in cell therapy and tissue engineering. Methods: In this study, we proposed an innovative, non-enzymatic protocol to collect clinically useful ASCs within freshly isolated SVF from adipose tissue by centrifugation of the infranatant portion of lipoaspirate and to determine the characteristic cytofluorimetric pattern, prior to in vitro culture. Results: The SVF yielded a mean of 73,32 $\pm 10,89 \%$ cell viability evaluated with CALCEINA-FITC, i.e. cell-permeant dye. The ASCs were positive for PC7-labeled mAb anti-CD34 and negative for both PE-labeled mAb anti-CD31 and APC-labeled mAb anti-CD45. The frequency of ASCs estimated according to the panel of cell surface markers used was 51,06\% $\pm 5,26 \%$ versus the unstained ASCs subpopulation that was $0,74 \% \pm 0,84 \%$ ( $<<0.0001$ ). The ASCs events $/ \mu \mathrm{L}$ were $1602,13 / \mu \mathrm{L} \pm$ $731,87 / \mu \mathrm{L}$.

Conclusion: Our findings suggested that ASCs found in freshly isolated adipose SVF obtained by centrifugation of lipoaspirate can be immunophenotypically identified with a basic panel of cell surface markers. These findings aimed to provide standardization and contribute to reducing the inconsistency on reported cell surface antigens of ASC derived from the existing literature.

Keywords: Adipose-derived Stem Cell; Flow-Cytometry; Mesenchymal Stem Cell; Stromal Vascular Fraction; Immunophenotyping; Immunohistochemistry; Fluorescent Antibody Technique; Cell Separation Method;

\section{Introduction}

Far from being an inert energy reservoir, adipose tissue is a highly bioactive tissue that has come more and more into the focus of regenerative medicine and tissue engineering in the last two decades. Mesenchymal stem cells (MSCs) can be obtained from adipose tissue and have appeared to be a particularly attractive and useful tool in cell therapy [14]. MSCs are a heterogeneous adult stem cell population of stromal progenitor cells that originate from the mesodermal layer of the embryo [5]. MSCs have been isolated from the stromal fraction of almost every type of adult and embryonic tissue in the body, including nervous tissue, skeletal muscle, dental tissues, adipose tissue, and in perinatal tissues such as the umbilical cord, Wharton's jelly, and the amniotic membrane [2, 6-9].

Adipose-derived stem cells (ASCs) are regarded as one of the most promising and attractive sources of adult or somatic stem cells identified thus far for cell therapy and regenerative medicine across a wide range of diseases [10]. ASCs are included in and isolated from the adipose tissue's stromal vascular fraction (SVF), which consists of a heterogeneous mesenchymal cell array, including not only ASCs but also preadipocytes, fibroblastic cells, endothelial cells, pericytes, vascular smooth muscle cells, hematopoietic lineage cells [11-15], macrophages and lymphocytes [16-18].

With the blossoming of the mesenchymal cell therapy's field for regenerative medical 
applications, the International Federation for Adipose Therapeutics and Science (IFATS) recommended clarification of the nomenclature for these cells by adopting the term adipose-derived stem cells or ASC referring to plastic-adherent, multipotent stromal cell population isolated from the SVF [19]. The investigators, that do not clearly show that these cells meet such criteria, should use the term "adipose-derived stromal cells", which is more scientifically accurate. Hence, the inclusive acronym of ASC can mean both. This article is conformed to the IFATS nomenclature and advocates its use.

Many different protocols for ASCs isolation appear in the literature [20], but a common standardized procedure is lacking, mostly due to the large inter- and intra-laboratory as well as donor-specific variabilities. The enzymatic digestion using manual or semiautomated systems to isolate ASC is the most common method [21,22] however, enzymatic treatment can affect the yield, quality, and effectiveness of ASCs, making them be considered more than "minimally manipulated," by U.S. Food and Drug Administration (FDA) guidance documents $[23,24]$. Therefore, although the procedure has proven effective, scientists have been interested in developing non-enzymatic or alternative methods to isolate ASCs starting with liposuction material [1,25-28] to make it less expensive and timeconsuming for clinical application. The non-enzymatic, i.e. mechanical dissociation, methods have been a topic of great interest because of the potential less restrictive regulatory approach set forth by the US FDA [23,24].

In addition, despite extensive in vitro ASC characterization, many important aspects regarding their in vivo biology were still unclear. Given their mesenchymal origin, it has been shown that the bona fide anatomical origin of MSCs in situ is the perivascular location of adult tissues, close to the artery and vein walls [29-31]. Specifically, it has been demonstrated that in the sinusoidal niches of bone marrow and the mural cell compartment of adipose and skeletal muscle vasculature the respective tissue progenitors reside [32-35]. Hence, the identification of perivascular MSC progenitors in human tissues has clarified the MSC identity in vivo and explains why they can be isolated from a multitude of organs $[7,31,35]$. The local environment in which the MSCs originate, the so-called stem cell niche, is of paramount importance in influencing and establishing the properties and phenotype of MSCs, resulting in many similarities and differences among the MSCs obtained from diverse human tissues [29-31].

For all the above-mentioned reasons, it is largely recognized by today's scientific community the necessity to establish a common isolation method and a standard characterization of human stromal and stem cells from SVF and ASCs to facilitate the comparison of the study outcomes and so the clinical research advancement within the field of adipose science. In this study, we proposed an innovative, non-enzymatic protocol to collect clinically useful ASCs within freshly isolated SVF from adipose tissue by centrifugation of the infranatant portion of lipoaspirate and to determine the characteristic cytofluorimetric pattern, prior to in vitro culture.

\section{Materials and Methods}

\subsection{Cell Harvesting and Processing}

The study was performed at Vista Vision between September 2018 and December 2019. Human adipose-derived stem cells included in SVF were obtained from patients under full approval of Low Vision Academy's Institutional Review Board and under the tenets of the 1964 Declaration of Helsinki (No. 2017/MC057, 4 May 2017). Informed consent was obtained from all subjects involved in the study. The harvest of the adipose tissue of the abdomen was surgically removed from patients during elective ocular surgery [36] by PL, MD, in the operating room of Vista Vision. The harvest and the post-harvest fat processing method were conducted according to the Coleman technique by two trained doctors, CL and MT. Briefly, $10 \mathrm{~mL}$ of fat are harvested from the abdominal subcutaneous layer of each patient using a 3-mm blunt cannula connected to a locking syringe. The lipoaspirate is then centrifugated at $1500 \mathrm{~g}$ of speed for $5 \mathrm{~min}$ at $20^{\circ} \mathrm{C}$ to eliminate nonviable components, including cellular debris and oil [37]. Finally, the bottom fluid portion of 
lipoaspirate from the centrifugated fat was drained, discarding blood, water, and aqueous components [38]. This method has demonstrated to obtain a higher concentration of adipose-derived mesenchymal stem cells within aspirate, reporting no damages to the structural integrity of adipose tissue and increased content of growth factors [39].

\subsection{Cell Isolation}

SVF was obtained from patients affected with eye diseases who underwent elective surgery and were isolated under fresh conditions. The isolation of SVF was manually performed from each patient's lipoaspirate in a clean room near the operating room, according to a previously described method [40]. Briefly, the adipose portion of the lipoaspirate was washed with phosphate-buffered saline (PBS; Biological Industries) and mix with 2.5 $\mathrm{mg} / \mathrm{ml}$ collagenase type II (Worthington Biochemical Corporation, Lakewood, NJ) for the enzymatic digestion. The collagenase/adipose mixture was placed in a $37^{\circ} \mathrm{C}$ water bath for $30 \mathrm{~min}$. to create a single-cell suspension and then filtered through a $100 \mu$ cell strainer and finally to a $45 \mu$ mesh. It was centrifugated for $5 \mathrm{~min}$. at $1200 \mathrm{xg}$ to collect the cellular SVF as a pellet.

\subsection{Flow Cytometry}

Once isolated, characterization of the cell composition of freshly-isolated SVF has been accomplished through multi-color flow cytometry (CytoFLEX Flow Cytometer, Backman Coulter, USA) that allows the identification of the surface marker expression of the cells in vitro. The panel of cell surface antigens was chosen in agreement with IFATS and the International Society for Cellular Therapy (ISCT) recommendations [10]. The immunophenotypic analysis is performed to confirm the mesenchymal nature of isolated cells. The following fluorochrome-labeled monoclonal antibodies were used for SVF analysis: CD31-PE, CD34-PC, and CD45-APC (Backman Coulter, USA) (Table 1).

- CD31 or platelet endothelial cell adhesion molecule (PECAM-1) is normally found on endothelial cells, platelets, macrophages and Kupffer cells, granulocytes, lymphocytes, megakaryocytes, and osteoclasts

- CD45 or protein tyrosine phosphatase, receptor type, C (PTPRC), Leukocyte common antigen (LCA), panhematopoietic marker expressed on all human white blood cells

- CD34, cell-cell adhesion molecule, a marker for pluripotent stem cell, expressed on all hematopoietic progenitor cells

The markers were used in combination with ViaKrome (Backman Coulter, USA), which determines cell viability, excluding debris and dead cells induced by the isolation protocol. Cells were incubated with specific mAbs for $15 \mathrm{~min}$. At least $10^{5}$ cells were acquired from each sample. The software CytEpert Version 2.2.0.97, CytoFLEX (Beckman Coulter, Inc) was used to create dot plots and to calculate the cell composition percentages according to the profile of the surface marker expression. 


\begin{tabular}{|l|l|l|l|}
\hline \multicolumn{1}{|c|}{ Table 1. Antibodies used in this study } \\
\hline $\begin{array}{l}\text { Fluorochrome-labeled } \\
\text { monoclonal antibodies }\end{array}$ & \multicolumn{1}{|c|}{ Target protein } & \multicolumn{1}{c|}{ Supplier } & \multicolumn{1}{c|}{ Catalog No. } \\
\hline CD31-PE & PECAM-1 & $\begin{array}{l}\text { Beckman Coulter, CA, } \\
\text { USA }\end{array}$ & $\begin{array}{l}1 \mathrm{~F} 11,100 \text { Tests, RUO } \\
\text { IM2409 }\end{array}$ \\
\hline CD34-PC7 & gp105-120 & $\begin{array}{l}\text { Beckman Coulter, CA, } \\
\text { USA }\end{array}$ & $\begin{array}{l}581,100 \text { Tests, CE } \\
\text { A21691 }\end{array}$ \\
\hline CD45-APC & LCA & $\begin{array}{l}\text { Beckman Coulter, CA, } \\
\text { USA }\end{array}$ & $\begin{array}{l}\text { J33, 100 Tests, CE } \\
\text { IM2473 }\end{array}$ \\
\hline CD = Cluster of Differentiation; PECAM-1 = platelet endothelial cell adhesion molecule; LCA: leucocyte common antigen \\
\hline
\end{tabular}

\subsection{Statistical analysis}

All statistical analyses were performed using software SPSS Statistics (version 20.0, SPSS Inc, Chicago, IL). Data were summarized with the mean \pm standard deviation (SD) and minimum and maximum (min-max) values were also reported. The student's paired t-test was used to compare values between stained cells and unstained controls. A $p$ value $<0.001$ was considered statistically significant.

\section{Results}

\subsection{Patient Characteristics}

A total of 32 patients with atrophic AMD (15 males and 17 females; mean age 69.4 years, range 50-83 years) undergoing elective surgery were recruited for the study. Table 2 shows the clinical features of the enrolled patients.

\begin{tabular}{|l|}
\hline Table 2. Characteristics of Patients \\
\hline Parameters \\
\hline Patients, $\mathrm{n}$ \\
\hline Age, years (range) \\
\hline Sex, n (\%) \\
Male
\end{tabular}

\subsection{ASCs Immunophenotypic Characterization}

For immunophenotypic characterization of ASCs within the SVF, freshly isolated cells were examined for surface antigen expression using flow cytometry. Flow cytometry data were gated (Fig. 1) to identify possible stromal cell subpopulations. The SVF yielded a mean of 73,32 $\pm 10,89 \%$ cell viability evaluated with CALCEINA-FITC, i.e. cell-permeant dye, to reduce the analysis distortion caused by the possible presence of dead or apoptotic cells. The ASCs were positive for CD34 and negative for CD31 and CD45. The frequency of ASCs estimated according to the panel of cell surface markers used was $51,06 \% \pm 5,26 \%$ versus the unstained ASCs subpopulation that was $0,74 \% \pm 0,84 \%$ 
$(\mathrm{P}<0.0001)$. The ASCs events/ $\boldsymbol{\mu} \mathrm{L}$ were $1602,13 / \mu \mathrm{L} \pm 731,87 / \boldsymbol{\mu L}$. The results of this analysis are shown in Figures 1, 2, 3, and Table 3.
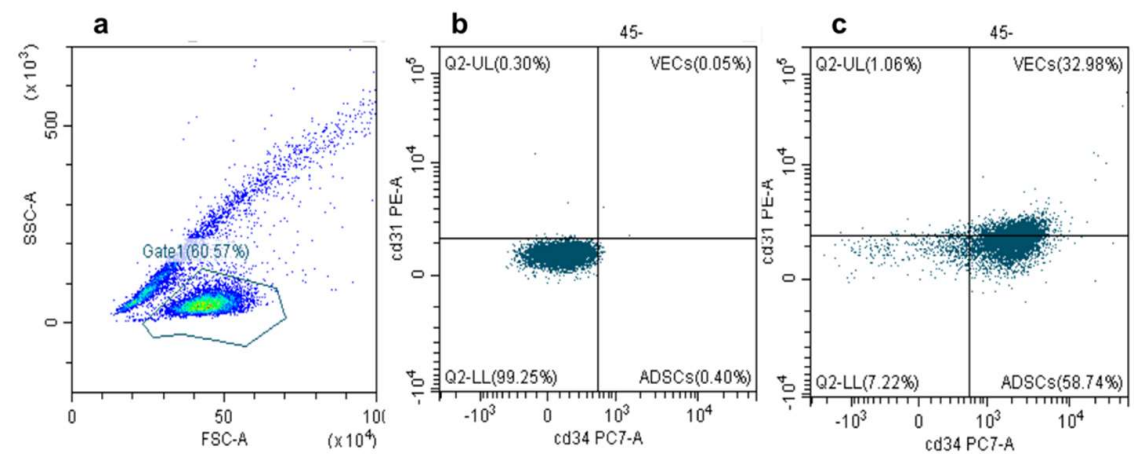

Figure 1. Representative flow cytometric histograms of adipose-derived stem cells within the SVF. Fluorescent dot plot showing cells within the freshly-isolated lipoaspirate (a). Dot plot showing cells unstained (b) and stained by antibodies directed against CD45, CD31, CD34 (c). The results are presented in brackets as a percent of positively stained cells.
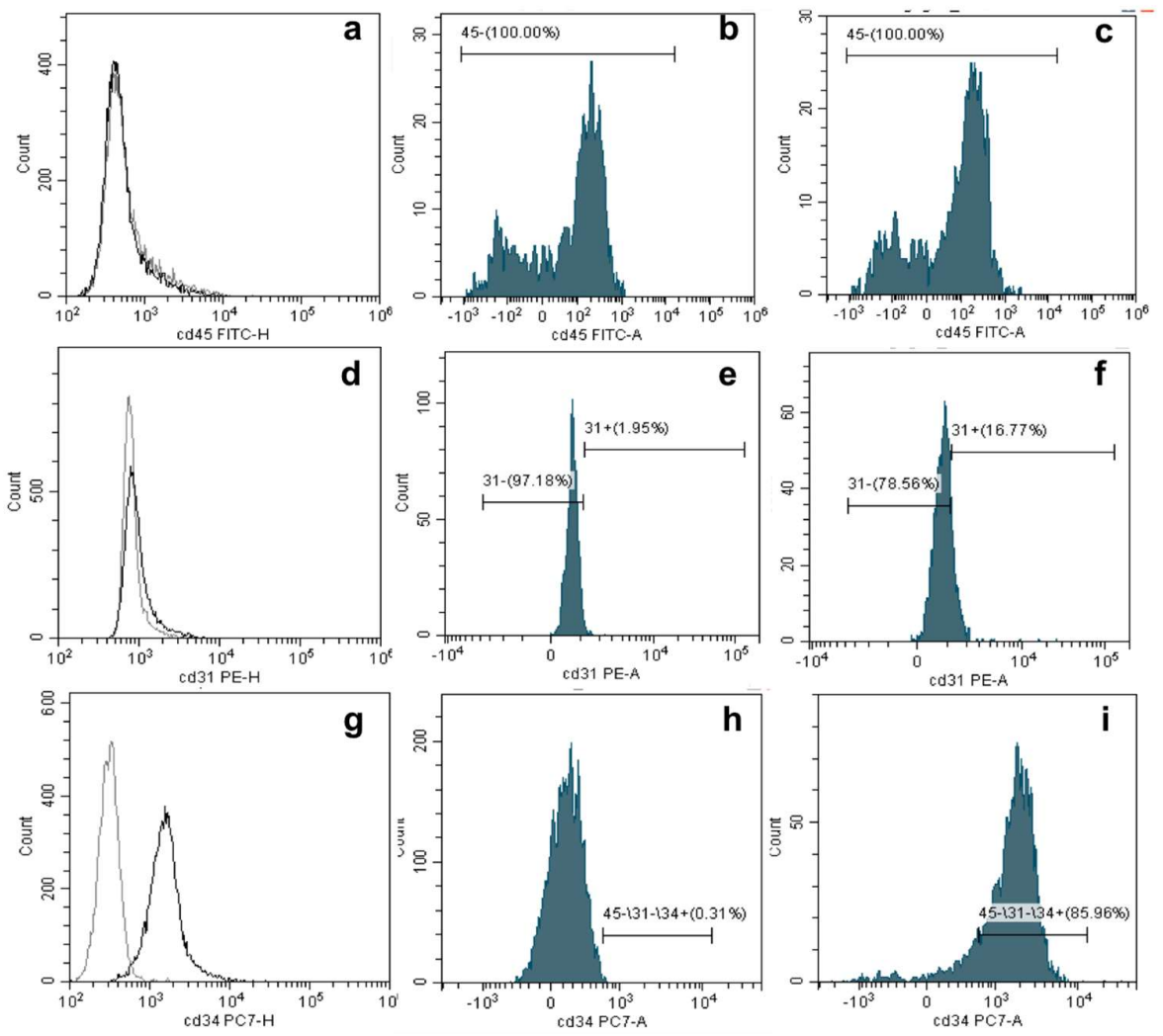

Figure 2. Immunophenotype characterization of ASCs represented by two-dimensional flow cytometry histograms. $(\mathrm{a}, \mathrm{d}, \mathrm{g})$ Histograms represent an isotype-matched negative $\mathrm{Ab}$ control (gray line) and Abs against CD45, CD31, CD34 respectively (black line); (b, e, h) histograms represent control antibody staining; Histograms displaying staining for CD45-FITC, the panhematopoietic marker (c), CD31-PE, found on endothelial cells, platelets and leukocytes (f) and CD34-PC, marker for pluripotent stem cells (i). Insets indicate markers and percentages of positively stained cells. Specific-marker fluorescence intensity and cell counts are indicated in abscissa and ordinate respectively. 
Table 3. Phenotype characterization by flow cytometry of cell fractions in the stromal vascular fraction

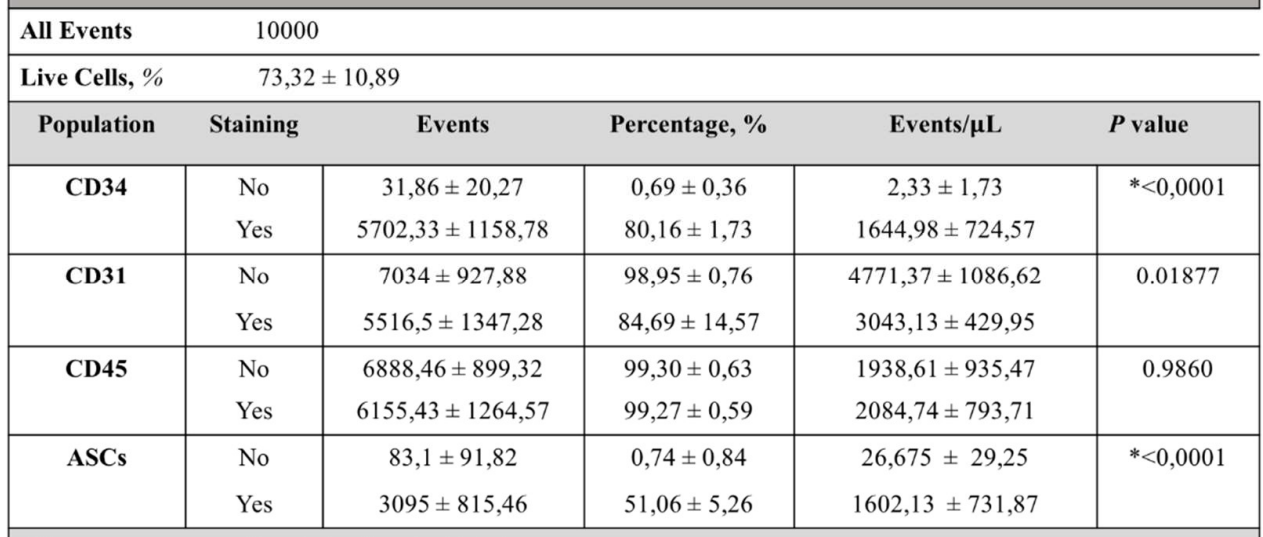

Values were compared by student's paired t-test.

$m=$ Mean; $\mathrm{SD}=$ Standard Deviation; $\mathrm{ASC}$ = Adipose derived stromal/stem cells

*Statistical Significance with P value $=0,0001$
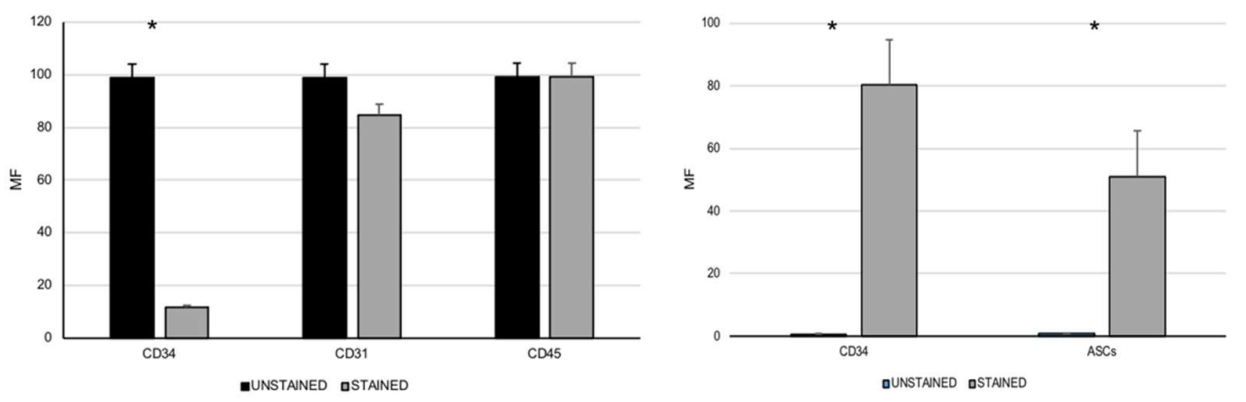

Figure 3. Phenotype characterization by flow cytometry of cell fraction in the stromal vascular fraction containing ASCs. Freshly isolated SVF cells were analyzed using three specific $\mathrm{mAb}$ antibodies labeled with three different fluorochromes: PE-labeled $\mathrm{mAb}$ anti-CD31, PC7-labeled mAb anti-CD34, APC-labeled mAb anti-CD45. The CD31- CD45- cell fraction was gated to characterize the ASCs population that was $\mathrm{CD}_{4}{ }^{+}$. Data are expressed as mean and standard error. $\mathrm{N}=32 .{ }^{*} \mathrm{P}-$ value $>0,0001$ Unstained $v s$. Stained. MF = Mean Fluorescence; ASCs = adipose-derived stem cell.

\section{Discussion}

In the present study, we determined the cytofluorimetric pattern of ASCs within freshly isolated SVF obtained by centrifugation of the infranatant portion of lipoaspirate from adipose tissue. Multicolor flow cytometry assays were used to identify and quantify surface marker profiles of cells, showing different subpopulations within the adipose SVF. The main populations within the crude SVF have been identified based on distinct immunophenotype: blood-derived cells, that are positive for CD45; adipose-derived cells, that are negative for $\mathrm{CD} 45$; the latter subset was further divided into vascular endothelial cells $\mathrm{CD} 31^{+} \mathrm{CD} 4^{+}$and stem cells from the adipose tissue-derived stromal vascular fraction (native ASC in the SVF), that have a negative expression for CD31 and positive expression for CD34. The SVF composition, fresh ASCs yield, and cell viability in our sample set were relatively consistent, suggesting that the isolation protocol was successfully performed.

CD45 marker, LCA, is commonly used to identify peripheral blood-derived cells, excluding erythrocytes, and allows to exclude blood cells contained in the liposuction aspirates for the substantial amount of hemorrhage [40]. The negativity of ASCs for CD45 is consistent with their mesodermal origin $[1,10]$.

CD31 marker, platelet-endothelial cell adhesion molecule-1 or PECAM-1, is the classic marker for endothelial cells and their precursors and, in combination with CD45 and CD31 allows to exclude the CD45- CD31+ endothelial sub-population [10]. 
CD34 marker has been shown to be expressed by hematopoietic stem cells and by other mesenchymal precursors $[1,10]$. It has recently been accepted that freshly isolated ASCs and other native MSCs in vivo express CD34; nevertheless, its expression decreases until disappearing after a short culture time in vitro [41, 42].

It is recommended to choose the class III CD34 antibodies to characterize the SVF cells with the most consistent signal intensity, given that different classes of CD34 antibodies exist and detect specific epitopes, influencing the signal intensity detected on a given cell population [10]. Indeed, the percentage of $\mathrm{CD}^{2} 4^{+}$positive cells is variable from $80 \%$ to $3,5 \%$ among investigators, depending on the harvesting methods and isolation techniques [10, 43,44]. Other additional surface markers, best used in combination with others, have been proposed to better identify stromal cells within SVF: CD13 (aminopeptidase N) and CD73 (lymphocyte-vascular adhesion molecule-2), CD90 (Thy-1), CD105 (endoglin), CD29 (b1 integrin) and CD44 (homing cell adhesion molecule). Other secondary positive markers are CD10 (CALLA), CD26 (dipeptidyl peptidase-4), CD36 (fatty acid translocase), CD49 (Very Late Antigen-4) isoforms. Primary stable negative marker are CD31 (PECAM-1), CD45 (LCA), CD235a (glycophorin A) (<2\%) [10].

Although the immunophenotype of ASC is relatively congruent between independent investigators, the characterization of both ASCs and cellular contents of freshly-isolated SVF is still lacking standardization, hindering the comparison of the study outcomes and so the clinical research advancement within the field of adipose science.

The principal hampering points for the characterization of both SVF cells and ASCs are mostly due to the large inter- and intra-laboratory as well as donor-specific variabilities.

Firstly, variability between donors, in terms of age, gender, ethnicity, body mass index, and pre-existing diseases can contribute to determining heterogeneity in the cell populations and so the antigen expression. Secondly, the several differences in anatomical harvest site, the high variation in the range of cell isolation methods, post-isolation processing, and culture protocols are likely to skew the distribution of the SVF constituents $[10,45-49]$. A variety of techniques to obtain adipose tissue can be drawn from the literature, all aiming to reduce the occurrence of cellular damage and to preserve the tissue architecture. The most widely used harvest approaches are needle biopsy or liposuction aspirate; the latter one is preferable for clinical purposes as it has been reported to provide higher proliferation potential and higher differentiation rate than fat biopsy, without significantly alter the viability of SVF cells [46]. Finally, the last step is the isolation of ASCs. The purified ASCs from SVF can be used either as freshly isolated or cultured and a variety of methods have been described by different Authors.

Up to now, the method for ASC isolation described in 2001 by Zuk [1] and coworkers is still the most commonly used. According to established methodologies [1], the freshly harvested lipoaspirate is washed with sterile phosphate-buffered saline (PBS), then the $\mathrm{ECM}$ is digested at $37^{\circ} \mathrm{C}$ for $30^{\prime}$ with $0.075 \%$ collagenase in order to isolate the SVF. To avoid over-digestion, the reaction is then neutralized with Dulbecco's modified Eagle's medium (DMEM) containing 10\% FBS and the cell suspension is centrifugated at $1200 \times g$ for $10 \mathrm{~min}$. The centrifugation allows separating the SVF, which forms a pellet at the bottom of the tube, from the mature adipocytes, oil, and cellular fragments which rise to the surface. The SVF pellet is resuspended in $160 \mathrm{mM} \mathrm{NH} 4 \mathrm{Cl}$ and incubated at room temperature for $10 \mathrm{~min}$ to lyse red blood cells, then it is centrifugated again (1200× $g$ for $10 \mathrm{~min}$ ) and filtered through a $100-m \mathrm{~m}$ nylon mesh in order to remove tissue fragments generated by the enzymatic procedure. Freshly isolated SVF cells are seeded into culture at $37^{\circ} \mathrm{C}$ in an atmosphere of $5 \%$ carbon dioxide (CO2). The culture medium contains $10 \%$ Fetal Bovine Serum, 1\% penicillin and streptomycin, and $1 \mathrm{mM}$ Glutamine. After the overnight incubation, the plates are extensively washed with PBS to remove any cellular debris, so that only the plastic-adherent cell population can be selected: the ASCs.

Since Zuk et al, many procedures to isolate and culture ASCs have been proposed that can differ very significantly, although they all stick to standard steps. As mentioned, the enzymatic digestion using manual or semiautomated systems to isolate ASC is the 
most common method [21,22] and consists of four steps: digestion, washing, centrifugation, and erythrocyte lysis. There is a consensus regarding digestion duration times (range of $30 \mathrm{~min}$ to $>1 \mathrm{~h}$ ) and temperature (37C). Finally, washing, centrifugation parameters, red blood cell lysis solution, and procedures, alongside filtration and culture conditions can substantially differ according to the protocols. Therefore, although the procedure has proven effective, many alternative, non-enzymatic methods have been described.

For example, Rada et al. [50] have described a novel isolation method for ASCs from SVF using antibody-coated immunomagnetic beads. Compared to the standard enzymatic method, they demonstrated a lower yield of ASCs, but with a higher expression of stem cell markers and with better capacity for differentiation.

Yoshimura et al. [40] were among the first to employ a non-enzymatic digestion protocol investigating the fluid portions of liposuction aspirates as sources of ASCs and concluding that it may provide clinical utility similar to the conventional isolation method.

Baptista et al. [51] have described a mechanical tissue digestion method to isolate ASC from lipoaspirate samples, concluding that it is cost-effective, time-saving, and gives a higher yield of cells compared to the digestion method.

However, similar to the enzymatic procedures, the range of protocols for mechanical procedures also has shown high variations. In addition, several benchtop mechanical devices have been fabricated to automate the ASC isolation process bypassing the cell expansion step and make it suitable for immediate clinical applications [21], however, they are limited by the low number of stem cells.

In addition to this confusing mosaic, other discrepancies among authors are in the panel of antigens used for cell characterization, the threshold chosen for positive or negative staining, the not well-standardized gating parameters [10].

Another issue that complicates the comparisons between studies is that the characterization of ASC surface markers substantially differs between freshly isolated ASCs in the SVF of adipose tissue and culture-expanded ASC [1, 10, 48-49].

More characterization studies to identify the native ASCs population are needed. Therefore, it represents a dynamic and rapidly evolving area of research.

To the best of our knowledge, we proposed a basic cytofluorimetric pattern of in vivo ASC population found in freshly isolated SVF obtained by centrifugation of the infranatant portion of lipoaspirate from adipose tissue without purifying them by adherent culture isolation and expansion in vitro. We used a combination of positive and negative markers in the same multiparameter flow cytometric analysis to phenotype the cells and one viability dye to exclude apoptotic cells and other debris, indicating viability of $\geq 70 \%$ for ASCs, according to IFATS recommendations.

The limitations in the present study were the restricted sample size, the small number of cytofluorimetric markers used, and the lack of functional characterization, which could be the subject for future studies.

\section{Conclusions}

Recently, clinical research on adipose tissue and the heterogeneous populations within its SVF has accelerated, and several scientific investigations are ongoing to examine the use of ASCs and SVF cells in regenerative medicine and tissue engineering [52]. To date, it is challenging to define a common isolation method and characterization profile of ASC found in the adipose tissue due to the discrepancy among researchers' protocols and the small number of reports. Therefore, our study stemmed from this urgent need, fostering this collective effort of cell therapy standardization.

In the present study, we determined the cytofluorimetric pattern of ASCs within freshly isolated SVF obtained by centrifugation of the infranatant portion of lipoaspirate from adipose tissue. Multicolor flow cytometry assays were used to identify and quantify surface marker profiles of cells, showing that ASCs were positive for CD34 and negative for CD31 and CD45 (P-value $<0,0001)$. 
Further studies are needed to consolidate the immunophenotype identification of native ASCs, which should be considered dynamic, to support their significant clinical utility for regenerative medicine applications, and more importantly, to fully characterized all the subpopulations found in the adipose SVF. It would be extremely interesting to deepen the knowledge of the molecular characteristics, the functional properties, and the in vitro and in vivo differentiation potential of the MSCs and ASCs found within the blood vessels in vivo, as well as the relationships and the hierarchy of the subpopulation within the SVF.

Author Contributions: Conceptualization and writing: C.L. Data analysis: C.L. Investigation: C.L and P.G.L. Data curation: M.N.

Funding: This research received no external funding

Institutional Review Board Statement: The study was conducted according to the guidelines of the Declaration of Helsinki, and approved by the Institutional Review Board of the Low Vision Academy (No. 2017/MC057, 4 May 2017)

Informed Consent Statement: Informed consent was obtained from all subjects involved in the study.

Data Availability Statement: In this section, please provide details regarding where data supporting reported results can be found, including links to publicly archived datasets analyzed or generated during the study. Please refer to suggested Data Availability Statements in section "MDPI Research Data Policies" at https://www.mdpi.com/ethics. You might choose to exclude this statement if the study did not report any data.

Acknowledgments: We are very grateful to Dr. Vincenzo Di Ruocco e Dr. Jorge Formaro (Beckman Coulter, Italy) for their technical assistance and their help with the isolation protocol setting up.

Conflicts of Interest: The authors declare no conflict of interest.

\section{References}

1. Zuk, P.A.; Zhu, M.; Mizuno, H.; Huang, J.; Futrell, J.W.; Katz, A.J.; Benhaim, P.; Lorenz, H.P.; Hedrick M.H.; Multilineage cells from human adipose tissue: implications for cell-based therapies. Tissue Eng. 2001, 2, 211-28. doi: 10.1089/107632701300062859.

2. Prunet-Marcassus, B.; Cousin B.; Caton D.; André M.; Pénicaud L.; Casteilla L. From heterogeneity to plasticity in adipose tissues: site-specific differences. Exp Cell Res. 2006, 6, 727-36. doi: 10.1016/j.yexcr.2005.11.021.

3. Gimble, J.; Guilak, F. Adipose-derived adult stem cells: isolation, characterization, and differentiation potential. Cytotherapy. 2003, 5, 362-9. doi: 10.1080/14653240310003026.

4. Bateman, M.E.; Strong, A.L.; Gimble, J.M.; Bunnell B.A. Concise Review: Using Fat to Fight Disease: A Systematic Review of Nonhomologous Adipose-Derived Stromal/Stem Cell Therapies. Stem Cells, 2018, 9, 1311-1328. doi: 10.1002/stem.2847.

5. Horwitz, E.M.; Andreef, M.; Frassoni F. Mesenchymal stromal cells. Biol. Blood Marrow Transplant. 2007,6 , 53-57. doi:10.1016/j.bbmt.2006.10.01653

6. da Silva Meirelles, L.; Chagastelles, P.C.; Nardi, N.B. Mesenchymal stem cells reside in virtually all post-natal organs and tissues. J Cell Sci, 2006, 11, 2204-13. doi: 10.1242/jcs.02932.

7. Kuznetsov, S.A.; Mankani, M.H.; Gronthos, S.; Satomura, K.; Bianco, P.; Robey, P.G. Circulating skeletal stem cells. J Cell Biol, 2001, 5, 1133-40. doi: 10.1083/jcb.153.5.1133.

8. Montanucci, P.; Basta, G.; Pescara, T.; Pennoni, I.; Di Giovanni, F.; Calafiore, R. New simple and rapid method for purification of mesenchymal stem cells from the human umbilical cord Wharton jelly. Tissue Eng Part A, 2011, 21-22, 2651-61. doi: 10.1089/ten.TEA.2010.0587.

9. Aghajani, F.; Hooshmand, T.; Khanmohammadi, M.; Khanjani, S.; Edalatkhah, H.; Zarnani, A.H.; Kazemnejad, S. Comparative Immunophenotypic Characteristics, Proliferative Features, and Osteogenic Differentiation of Stem Cells Isolated from Human Permanent and Deciduous Teeth with Bone Marrow. Mol Biotechnol, 2016, 6, 415-27. doi: 10.1007/s12033-016-9941-2.

10. Bourin, P.; Bunnell, B.A.; Casteilla, L.; Dominici, M.; Katz, A.J.; March, K.L.; Redl, H.; Rubin, J.P.; Yoshimura, K.; Gimble, J.M. Stromal cells from the adipose tissue-derived stromal vascular fraction and culture expanded adipose tissue-derived stromal/stem cells: a joint statement of the International Federation for Adipose Therapeutics and Science (IFATS) and the International Society for Cellular Therapy (ISCT). Cytotherapy, 2013, 6, 641-8. doi: 10.1016/j.jcyt.2013.02.006.

11. Cawthorn, W.P.; Scheller, E.L.; MacDougald, O.A. Adipose tissue stem cells meet preadipocyte commitment: going back to the future. J Lipid Res. 2012, 2, 227-46.

12. McIntosh, K.; Zvonic, S.; Garrett, S.; Mitchell, J.B.; Floyd, Z.E., Hammill, L.; Kloster, A.; Di Halvorsen, Y.; Ting, J.P.; Storms, R.W.; Goh, B.; Kilroy, G.; Wu, X.; Gimble, J.M. The immunogenicity of human adipose-derived cells: temporal changes in vitro. Stem Cells, 2006, 5, 1246-53. doi: 10.1634/stemcells.2005-0235. 
13. Mitchell, J.B.; McIntosh, K.; Zvonic, S.; Garrett, S.; Floyd, Z.E.; Kloster, A.; Di Halvorsen, Y.; Storms, R.W.; Goh, B.; Kilroy, G.; $\mathrm{Wu}, \mathrm{X}$; Gimble, J.M. Immunophenotype of human adipose-derived cells: temporal changes in stromal-associated and stem cellassociated markers. Stem Cells, 2006, 2, 376-85. doi: 10.1634/stemcells.2005-0234.

14. Cousin, B.; Andre, M.; Arnaud, E.; Penicaud, L.; Casteilla, L. Reconstitution of lethally irradiated mice by cells isolated from adipose tissue. Biochem. Biophys. Res. Commun. 2003, 4, 1016-22.

15. Han, J.; Koh, Y.J.; Moon, H.R.; Ryoo, H.G.; Cho, C.H.; Kim, I.; Koh, G.Y. Adipose tissue is an extramedullary reservoir for functional hematopoietic stem and progenitor cells. Blood, 2010, 5, 957-64. doi: 10.1182/blood-2009-05-219923.

16. Rodbell, M. Metabolism of isolated fat cells. Effects of hormones on glucose metabolism and lipolysis. J Biol Chem, 1964, 239, 357-380.

17. Rodbell, M. The metabolism of isolated fat cells. IV. Regulation of release of protein by lipolytic hormones and insulin. J. Biol. Chem, 1966, 241, 3909-3917.

18. Astori, G.; Vignati, F.; Bardelli, S.; Tubio, M.; Gola, M.; Albertini, V.; Bambi, F.; Scali, G.; Castelli, D.; Rasini, V.; Soldati, G.; Moccetti, T. "In vitro" and multicolor phenotypic characterization of cell subpopulations identified in fresh human adipose tissue stromal vascular fraction and in the derived mesenchymal stem cells. J Transl Med, 2007, 5, 55. doi: 10.1186/1479-5876-555.

19. Daher, S.R.; Johnstone, B.H.; Phinney, D.G.; March, K.L.. Adipose stromal/stem cells: basic and translational advances: the IFATS collection. Stem Cells, 2008, 10, 2664-5. doi: 10.1634/stemcells.2008-0927.

20. Raposio, E.; Bertozzi, N. Isolation of Ready-to-Use Adipose-Derived Stem Cell (ASC) Pellet for Clinical Applications and a Comparative Overview of Alternate Methods for ASC Isolation. Curr. Protoc. Stem Cell Biol, 2017, 41, 1F.17.1-1F.17.12.

21. Gimble, J.M.; Katz, A.J.; Bunnell, B.A. Adipose-derived stem cells for regenerative medicine. Circ Res, 2007, 100, 1249e60.

22. Bunnell, B.A.; Flaat, M.; Gagliardi, C.; Patel, B.; Ripoll, C. Adipose-derived stem cells: Isolation, expansion and differentiation. Methods. 2008, 45, 115-120.

23. Eligibility determination for donors of human cells, tissues, and cellular and tissue-based products (HCT/Ps). 21 CFR 1271. 2007.

24. Naghshineh, N.; Brown, S.; Cederna, P.S.; Levi, B.; Lisiecki, J.; D'Amico, R.A.; Hume, K.M.; Seward, W.; Rubin, J.P. Demystifying the U.S. Food and Drug Administration: understanding regulatory pathways. Plast Reconstr Surg, 2014, 3, 559-569. doi: 10.1097/PRS.0000000000000477.

25. Moore, J.H.; Jr, Kolaczynski, J.W.; Morales, L.M.; Considine, R.V.; Pietrzkowski, Z.; Noto, P.F.; Caro, J.F. Viability of fat obtained by syringe suction lipectomy: effects of local anesthesia with lidocaine. Aesthetic Plast Surg, 1995, 4, 335-9. doi: 10.1007/BF00451659. PMID: 7484471.

26. Lalikos, J.F.; Li, Y.Q.; Roth, T.P.; Doyle, J.W.; Matory, W.E.; Lawrence, W.T. Biochemical assessment of cellular damage after adipocyte harvest. J Surg Res, 1997, 1, 95-100. doi: 10.1006/jsre.1997.5090.

27. Halvorsen, Y.D.; Bond, A.; Sen, A.; Franklin, D.M.; Lea-Currie, Y.R.; Sujkowski, D.; Ellis, P.N.; Wilkison, W.O.; Gimble, J.M. Thiazolidinediones and glucocorticoids synergistically induce differentiation of human adipose tissue stromal cells: biochemical, cellular, and molecular analysis. Metabolism, 2001, 4, 407-13. doi: 10.1053/meta.2001.21690.

28. Katz, A.J.; Llull, R.; Hedrick, M.H.; Futrell, J.W. Emerging approaches to the tissue engineering of fat. Clin Plast Surg, 1999, 4, 587-603.

29. Tintut, Y.; Alfonso, Z.; Saini, T.; Radcliff, K.; Watson, K.; Boström, K.; Demer, L.L. Multilineage potential of cells from the artery wall. Circulation. 2003, 20, 2505-10. doi: 10.1161/01.CIR.0000096485.64373.C5.

30. Hoshino, A.; Chiba, H.; Nagai, K.; Ishii, G.; Ochiai, A. Human vascular adventitial fibroblasts contain mesenchymal stem/progenitor cells. Biochem. Biophys. Res. Commun., 2008, 2, 305-10. doi: 10.1016/j.bbrc.2008.01.090.

31. Crisan, M.; Yap, S.; Casteilla, L.; Chen, C.W.; Corselli, M.; Park, T.S.; Andriolo, G.; Sun, B.; Zheng, B.; Zhang, L.; Norotte, C.; Teng, P.N.; Traas, J.; Schugar, R.; Deasy, B.M.; Badylak, S.; Buhring, H.J.; Giacobino, J.P.; Lazzari, L.; Huard, J.; Péault, B. A perivascular origin for mesenchymal stem cells in multiple human organs. Cell Stem Cell. 2008, 3, 301-13. doi: 10.1016/j.stem.2008.07.003.

32. Kiel, M.J.; Yilmaz, O.H.; Iwashita, T.; Yilmaz, O.H.; Terhorst, C.; Morrison, S.J. SLAM family receptors distinguish hematopoietic stem and progenitor cells and reveal endothelial niches for stem cells. Cell, 2005, 7, 1109-21. doi: 10.1016/j.cell.2005.05.026.

33. Dellavalle, A.; Sampaolesi, M.; Tonlorenzi, R.; Tagliafico, E.; Sacchetti, B.; Perani, L.; Innocenzi, A.; Galvez, B.G.; Messina, G.; Morosetti, R.; Li, S.; Belicchi, M.; Peretti, G.; Chamberlain, J.S.; Wright, W.E.; Torrente, Y.; Ferrari, S.; Bianco, P.; Cossu, G. Pericytes of human skeletal muscle are myogenic precursors distinct from satellite cells. Nat Cell Biol, 2007, 3, 255-67. doi: $10.1038 /$ ncb1542.

34. Tang, W.; Zeve, D.; Suh, J.M.; Bosnakovski, D.; Kyba, M.; Hammer, R.E.; Tallquist, M.D.; Graff, J.M. White fat progenitor cells reside in the adipose vasculature. Science, 2008, 5901, 583-6. doi: 10.1126/science.1156232.

35. Traktuev, D.O.; Merfeld-Clauss, S.; Li, J.; Kolonin, M.; Arap, W.; Pasqualini, R.; Johnstone, B.H.; March, K.L. A population of multipotent CD34-positive adipose stromal cells share pericyte and mesenchymal surface markers, reside in a periendothelial location, and stabilize endothelial networks. Circ Res, 2008, 1, 77-85. doi: 10.1161/CIRCRESAHA.107.159475.

36. Limoli, P.G.; Limoli, C.; Vingolo, E.M.; Limoli, C.; Scalinci, S.Z.; Nebbioso, M. Regenerative therapy by suprachoroidal cell autograft in dry age-related macular degeneration: preliminary in vivo report. J. Vis. Exp. 2018, 132, e56469.

37. Lawrence, N.; Coleman, W.P. 3rd. Liposuction. J Am Acad Dermatol. 2002, 1, 105-8. doi: 10.1067/mjd.2002.122189.

38. Coleman, S.R. Structural fat grafting: more than a permanent filler. Plast Reconstr Surg, 2006, 3, 108S-120S. doi: 10.1097/01.prs.0000234610.81672.e7. PMID: 16936550. 
39. Pallua, N.; Pulsfort, A.K.; Suschek, C.; Wolter, T.P. Content of the growth factors bFGF, IGF-1, VEGF, and PDGF-BB in freshly harvested lipoaspirate after centrifugation and incubation, Plast. Reconstr. Surg, 2009, 123, 826-833.

40. Yoshimura, K.; Shigeura, T.; Matsumoto, D.; Sato, T.; Takaki, Y.; Aiba-Kojima, E.; Sato, K.; Inoue, K.; Nagase, T.; Koshima, I.; Gonda, K. Characterization of freshly isolated and cultured cells derived from the fatty and fluid portions of liposuction aspirates. J Cell Physiol, 2006, 1, 64-76. doi: 10.1002/jcp.20636.

41. Lin, G.; Garcia, M.; Ning, H.; Banie, L.; Guo, Y.L.; Lue, T.F.; Lin, C.S. Defining stem and progenitor cells within adipose tissue. Stem Cells Dev, 2008, 6, 1053-63. doi: 10.1089/scd.2008.0117.

42. Suga, H.; Matsumoto, D.; Eto, H.; Inoue, K.; Aoi, N.; Kato, H.; Araki, J.; Yoshimura, K. Functional implications of CD34 expression in human adipose-derived stem/progenitor cells. Stem Cells Dev, 2009, 8, 1201-10. doi: 10.1089/scd.2009.0003.

43. Gronthos, S.; Franklin, D.M.; Leddy, H.A.; Robey, P.G.; Storms, R.W.; Gimble, J.M. Surface protein characterization of human adipose tissue-derived stromal cells. J Cell Physiol, 2001, 1, 54-63. doi: 10.1002/jcp.1138. PMID: 11573204.

44. Corselli, M.; Chen, C.W.; Crisan, M.; Lazzari, L.; Péault, B. Perivascular ancestors of adult multipotent stem cells. Arterioscler Thromb Vasc Biol, 2010, 6, 1104-9. doi: 10.1161/ATVBAHA.109.191643

45. Ho, A.D.; Wagner, W.; Franke, W. Heterogeneity of mesenchymal stromal cell preparations. Cytotherapy, 2008, 4, 320-30. doi: 10.1080/14653240802217011.

46. Jurgens, W.J.; Oedayrajsingh-Varma, M.J.; Helder, M.N.; Zandiehdoulabi, B.; Schouten, T.E.; Kuik, D.J.; Ritt, M.J.; van Milligen, F.J. Effect of tissue-harvesting site on yield of stem cells derived from adipose tissue: implications for cell-based therapies. Cell Tissue Res, 2008, 3, 415-26. doi: 10.1007/s00441-007-0555-7.

47. Engler, A.J.; Sen, S.; Sweeney, H.L.; Discher, D.E. Matrix elasticity directs stem cell lineage specification. Cell, 2006, 4, 677-89. doi: 10.1016/j.cell.2006.06.044.

48. Tallone, T.; Realini, C.; Böhmler, A.; Kornfeld, C.; Vassalli, G.; Moccetti, T.; Bardelli, S.; Soldati, G. Adult human adipose tissue contains several types of multipotent cells. J Cardiovasc Transl Res, 2011, 2, 200-10. doi: 10.1007/s12265-011-9257-3.

49. Mitchell, J.B.; McIntosh, K.; Zvonic, S.; Garrett, s.; Floyed, Z.E.; Kloster, A.; Di Halvorsen, Y.; Storms, R.W.; Goh, B.; Kilroy, G.; $\mathrm{Wu}, \mathrm{X}$. Gimble, J.M. Immunophenotype of human adipose-derived cells: temporal changes in stromal-associated and stem cellassociated markers. Stem Cells 2006, 24, 376-385.

50. Rada, T., Reis, R.L.; Gomes, M.E. Novel method for the isolation of adipose stem cells (ASCs). J Tissue Eng Regen Med, 2009, 2, 158-9. doi: 10.1002/term.141.

51. Baptista L,S. Adipose stromal/stem cells in regenerative medicine: Potentials and limitations. World J Stem Cells, 2020, 1, 1-7. doi: 10.4252/wjsc.v12.i1.1.

52. Ankrum, J.; Karp, J.M. Mesenchymal stem cell therapy: Two steps forward, one step back. Trends Mol Med. 2010, 5, 203-9. doi: 10.1016/j.molmed.2010.02.005. 